\title{
The Covid-19 World: Learning or Downfall
}

\section{Juha Suoranta ${ }^{1}$}

Accepted: 1 September 2020 / Published online: 17 September 2020

(C) Springer Nature Switzerland AG 2020

Keywords Communication · Covid-19 · Critical pedagogy · Education · Semiosphere · Umwelt

\section{Umwelts United}

The award-winning Netflix drama Dark (Odar 2017-2020) is based on the idea of time travel through ages and between parallel worlds. A time cycle manipulated by a secret society of time travelers called Sic Mundus ends at an apocalypse over and over again. Unfortunately, the real world cannot be switched off or rewound as the German television drama. On the contrary: in the present, 'reality violently breaks in' (Coeckelbergh 2020, emphasis in original).

Covid-19 is a novel coronavirus, yet its causes are much older and well-known. For years, experts (e.g., Morse 1993) have warned of new pathogens that result from a combination of several, often amorphous factors: climate change, massive urbanization, the proximity of humans to farm or forest animals that serve as viral reservoirs, and the worldwide spread of microbes accelerated by war, global economy, and international air travel (Henig 2020; Lewis 2020). There are also other pressing questions, such as how we treat non-human animals (O'Sullivan 2020). Despite these discussions, it is commonly understood that the SARS-CoV-2 virus, which causes the Covid-19 disease, is a biological entity. Within this understanding, the Covid-19 pandemic represents an external biological threat or random 'force of nature.'

In Civilization and its Discontents, Sigmund Freud (1961: 24) states that human misery and suffering arise from three sources: from our bodies, which are 'doomed to decay and dissolution,' from the external world which rages against us without mercy, and from our relations to other human beings. In the context of Covid-19, Freud's typology is irretrievably outdated if read dichotomously (human beings here, nature

Juha Suoranta

juha.suoranta@tuni.fi

1 Tampere University, Tampere, Finland 
there), or fragmentally (as if different entities of the world did not form a whole). In the global world of mercurial flows and relations (of viruses, human beings, digital bits, material artifacts, and particles), approaches based on fragmentation are unable to describe the whole accurately (Peters 2020). As Morse (1993: viii) remarks, although viruses are biological of origin when 'the host is human, social factors can play a very significant role in both dissemination and expression of disease. On a larger scale, many epidemics can be understood only in their ecological context.'

As we try to make sense of the Covid-19 pandemic, it is critical to examine the complex interplay of viral behaviors in all spheres of life. Such complexity brings about the concept of 'viral modernity' that is 'based upon the nature of viruses, the ancient and critical role they play in evolution and culture, and the basic application to understanding the role of information and forms of bioinformation in the social world' (Peters, Jandrić, and McLaren 2020). Viral modernity may be a new theoretical concept, but its features can be traced throughout human history; 'the Covid-19 pandemic is merely the first global exercise of viral modernity' of the twenty-first century (Jandrić et al. 2020).

From Umweltforschung, founded by the Baltic German biologist Jakob von Uexküll (1864-1944), one can further argue that various entities, such as coronaviruses, have their Umwelts defined as objective totalities with 'significant surroundings,' standard forms and characteristics. The Umwelts coordinate and interact, in one way or another, with their habitats and provide identities to specific entities. The entity called SARS-CoV-2 also 'changes its meaning accordingly when perceived as one or the other, accompanied by modifications of the entirety of both its material and formal properties' (Sebeok 1986: 4).

An Umwelt is a transparent part of the web of sign relations that are 'at all times informational and energetic, spatial and temporal, objective and subjective' (Sebeok 1986: 23). It transpires within the boundaries of entities and interacts with other Umwelts in social semiosis or semiosphere (Lotman 2005). These concepts are essential for understanding the Covid-19 pandemic because they bring the Umwelts of viruses and other interacting entities of the world together (see also Peters, McLaren, and Jandrić 2020). The semiosphere unites the biological with psychological, social, and other Umwelts through the realm of communication.

\section{Communication: A Matter of Life and Death}

It is through communication (the use of language and words in the semiosphere) that the global Covid-19 pandemic is conceptualized, understood, and consequently (hopefully) overcome. As Angelika Bammer and Ruth-Ellen Boetcher Joeres write,

[w] ords are powerful, and what we do with them makes their power evident. When people write, they use that power - to present an argument, to convey new knowledge, to tell a story. Sometimes they write to change the way others see things, and in that sense, they write to change the world. Academic writers are no exception to these general principles. We write to make a difference too. Yet to 
our own chagrin and our readers' loss, we often fail to communicate effectively.

(Bammer and Boetcher Joeres 2015)

How to interpret the current Covid-19 pandemic and its foreseeable future, and how to succeed in communicating one's ideas - be they recommendations, research results, classroom lessons, or the news - is now a question of life and death.

Unfortunately, today's media is packed with disinformation and misinformation through unwitnessed, unreliable, and fake news. Journalists and researchers are doing their best to minimize their destructive consequences (MacKenzie and Bhatt 2020; Peters et al. 2020). The Covid-19 pandemic has also sparked an unprecedented amount of scientific research (Jandrić 2020). Nevertheless, there are so many scientific publications that no one can read them all (Peters et al. 2020) or evaluate their scientific quality. 'By one estimate, the COVID-19 literature published since January has reached more than 23,000 papers and is doubling every 20 days - among the biggest explosions of scientific literature ever' (Brainard 2020).

Researchers are tackling this problem using many strategies, including the establishment of various literary troves and open repositories such as Cord-19 ${ }^{1}$ and Novel Coronavirus Research Compendium, ${ }^{2}$ as well as algorithms and data mining tools. ${ }^{3}$ Many science publishers have opened up their journals to the rapid publication of new research about the Covid-19 pandemic (Postdigital Science and Education among them). These actions are necessary, but far from enough, for coping with the Covid-19 epidemic and its successors.

Despite such abundance of Covid-19 research, it seems that ' $[\mathrm{m}] \mathrm{en}$ are winning the COVID-19 publishing game and women are losing out' (Flaherty 2020) because, on average, women have been doing more parenting and domestic labor than men during the pandemic and school closures (Vincent-Lamarre, Sugimoto, and Larivière 2020). As an economist, Olga Shurchkov (2020) puts it: 'Almost overnight, COVID-19 turned me into an elementary school teacher, a housekeeper, a hairdresser, and a professional worrier - all things I am terrible at, with the exception of the latter. My full-time job as an academic economist has become an afterthought.'

Social scientists and educators must meet the triple task of studying, teaching, and learning the 'new normal.' We need more validated social scientific research information on how people are thinking and acting, and we need viable policy recommendations for handling the current and future pandemics. We need to know how people in different parts of the world and different cultures react to Covid-19. People's living conditions differ as well as forms and degrees of suffering. Thus, we 'are all in the same storm, but not in the same boat' (Vincent-Lamarre et al. 2020) and certainly not all online (Selwyn and Jandrić 2020). When it comes to the coronavirus, we are cruelly unequal.

The Covid-19 pandemic has caused political turbulence and inspired conspiracy theories. For instance, the far-right Reichbürger movement in Germany (see Dick 2018) rallies for 'freedom,' claiming that the pandemic is a government plot aimed at

\footnotetext{
${ }^{1}$ See https://www.semanticscholar.org/cord19. Accessed 8 August 2020.

${ }^{2}$ See https://ncrc.jhsph.edu/. Accessed 8 August 2020.

${ }^{3}$ See https://scisight.apps.allenai.org/ and https://www.kaggle.com/covid-19-contributions. Accessed 8 August 2020.
} 
developing political repression. Others seem to believe that economic elites, such as Bill and Melinda Gates, rule the World Health Organization and that their attempts to develop a vaccine are a mere cover for the implementation of under skin chip implants aimed at broad scale behavior control (see Grossman 2020; McLaren 2020).

At the same time, tens of millions of people are at risk of starving to death due to the pandemic as Food and Agriculture Organization of the United Nations and World Food Program report (Amoo-Adare 2020; FAO and WFP 2020). UNESCO warns that 'Covid-19 school closures around the world will hit girls hardest.' Increased drop-out rates 'will disproportionately affect adolescent girls, further entrench gender gaps in education and lead to increased risk of sexual exploitation, early pregnancy, and early and forced marriage' (Giannini 2020). Moreover, Bonilla-Molina (2020) shows that the Covid-19 educational landscape includes numerous other problems, such as lack of online educational resources, online pedagogies, and teacher training. Unsurprisingly, these problems are especially prominent in the Global South.

\section{Critical Pedagogy of the New Normal}

Once we realize that there is no return to the pre-Covid-19 normal (Jandric and Hayes 2020), we hopefully see the condition of the world point-blank. Amid the apparent pandemic-induced chaos, we also need to imagine and constructively indicate 'what is' and 'what could be': the (in)famous new normal and a critical pedagogy of the new normal. A good part of this pedagogy consists of raising critical awareness about complex, interwoven problems plaguing today's world. The new normal extends critical pedagogy's traditional areas of interest: we must confront climate change (Lewis 2020), extreme nationalism (Yan 2020), racism (Chang 2020), religious-based fundamentalism (McLaren 2020), gender issues (Hurley 2020; Khan, Ratele, and Arendse 2020), nuclear and other war armaments (Wagener 2020), and many other problems that we may not even be aware of at the moment. Notably, the critical pedagogy of the new normal must reclaim democracy and seek alternatives for the global neoliberal order (Carr 2020a). Critical researchers need to fight to abolish predatory capitalism that accumulates wealth for a few and leaves the majority in poverty. We all need to unlearn the consumerist mindset (see Carr 2020b). In the post-Covid-19 era, critical pedagogues must

unionize, create revolutionary parties, build social movements, take to the streets, and develop community organizations: but we can also call out racist microaggressions when we see them, promote a curriculum that challenges the status quo, oppose destructive organizational priorities or take the necessarily vague language of mission statements and co-opt it for unexpected purposes. Justice work is done in big movements but also in small actions. (Brookfield 2016: 28)

A critical pedagogy of the new normal demonstrates that a systemic change cannot be avoided and acknowledges an important lesson learned during the Covid-19 pandemic: we live in the same world, and international cooperation, instead of protectionism, is needed at all levels. As Teräs, Suoranta, Teräs, and Curcher (2020) remind in this issue, '[t]he 
Covid-19 pandemic is not the end of the world, yet it could mean the end of $a$ world of corporate greed in the pre-/context of predatory capitalism.' In the world with Covid-19,

- Teachers need to redefine their role as agents of socialization. During school closures, worldwide teachers have noticed that 'many students are missing and cannot be reached online: a demonstration that schooling is not only about teaching and learning but also about social control' (Jandrić et al. 2020). Thus, teachers need to conscientize that formal schooling operates inside state apparatuses and that their role needs to reach far beyond training students to reproduce given curricula. In the new normal, it is more important than ever that teachers act as public intellectuals (Giroux 2005) and teach democratic principles and practices.

- We need open teaching and learning materials (books, online materials, courses, op-eds, policy recommendations) and a renewed non-fragmentary paradigm of teaching and learning in post-pandemic times. It is urgent, among other things, that we continuously study the advantages and disadvantages of online learning under various circumstances (Green, Burrow, and Carvalho 2020; Zhu and Liu 2020).

- Learning should be continuous and free from time and place. Students and non-students should be encouraged to self-study and self-organize with all those who are willing to learn. Curricula must be broad, informative, and co-created with students. Therein lie the art and beauty of learning how to coordinate our actions collectively (Rapanta, Botturi, Goodyear, Guàrdia, and Koole 2020).

- Learning should be understood beyond the limits of formal education. It should echo traditions and values developed through the long history of free/radical education: self-education ('autodidactism'), intrinsic motivation, respect for and utilization of learners' visions and life experiences, inclusion of everyone according to their needs and abilities (see Green et al. 2020). Study materials should be accessible to all and freely downloadable from online collections along with the free provision of the Internet (Suoranta 2020).

- All forms of learning collaboration should produce an empowering mindset: 'together we know, and together we can.' As Hardt and Negri point out,

self-education, of course, doesn't mean getting rid of teachers or tearing down the schools. It means instead that these relationships and institutions have to be oriented toward creating environments conducive to study. The greatest gift a teacher can give is the recognition that each student has the power to think and the desire to use that intelligence to study. (Hardt and Negri 2012: 41)

- Nation states should side with open and free educational groups and associations, NGOs, and learning projects of the civil society. They should support activities that serve the public interest, such as publication of (low circulation) non-fiction, development and maintenance of free digital learning platforms and social software (such as Wikiversity ${ }^{4}$ ), and so on. Hybrid strategies in education and learning, which combine the digital and the non-digital (see Lovink and Rossiter 2018: 51-

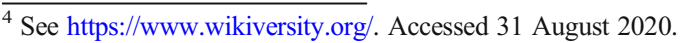


52), are these days unavoidable, and their development is a smart move (see Jandric et al. 2018). In the new normal, these and other strategies should open up institutional education and enable students to read the word and change the world.

Voices that call for a full scale social, political, economic, and spiritual change of Western-style consumerism are becoming louder and louder. However, we seem to be suffering from information fatigue - the phenomenon sociologist Georg Simmel, already in 1903, referred to as 'intensification of nervous stimulation' (Simmel 1950: 410). Under the circumstances, it is difficult to see that we have been living fragmented and uncertain lives at the crossroads for quite a long time (Bauman 2001: 127; see also Bauman 1995). These days, Covid-19 merely increases these symptoms and, as Amoo-Adare (2020) notes, 'is dragging us kicking and screaming into many "unknown unknowns",

We need to ensure that the many unknowns of the Covid-19 pandemic do not fulfill the grim prediction of 'organized irresponsibility' (Mills 2000: 338). Otherwise, the pandemic could produce 'a hypnotic paralysis which makes the crowd follow to its extreme every leading, suggestive impulse' (Simmel 1950: 228). To the best of our abilities, we need to prevent these tendencies from gaining popularity and becoming the new normal. Writing, teaching, and debating the Covid-19 pandemic should hopefully create an atmosphere that values scientific research and public rationality. This project requires everyone's contribution. Using C. Wright Mills' (2002: 132) typology, we need producers who create original research and ideas, wholesalers who distribute those ideas in journals and textbooks, and retailers who teach students and the broader public. We also need activist researchers (Freire 2018; Hale 2001), public sociologists (Burawoy 2005), and everyone willing to engage in solidarity with progressive, peaceful, and democratic social movements, voluntary groups, and other collectives. The road ahead is 'made by walking' (Horton and Freire 1990), and the future is open: learning or downfall.

\section{References}

Amoo-Adare, E. A. (2020). The art of (un)thinking: When hyper productivity says 'enough!', is a feast. Postdigital Science and Education. https://doi.org/10.1007/s42438-020-00162-z.

Bammer, A., \& Boetcher Joeres, R.-E. (2015). Introduction. In A. A. Bammer \& R.-E. B. Joeres (Eds.), The Future of Scholarly Writing. New York: Palgrave.

Bauman, Z. (1995). Life in fragments. Essays in postmodern morality. Oxford: Blackwell.

Bauman, Z. (2001). The individualized society. Cambridge: Polity Press.

Bonilla-Molina, L. (2020). Covid-19 on route of the fourth industrial revolution. Postdigital Science and Education. https://doi.org/10.1007/s42438-020-00179-4.

Brainard, J. (2020). Scientists are drowning in COVID-19 papers. Can new tools keep them afloat? Science. https:/www.sciencemag.org/news/2020/05/scientists-are-drowning-covid-19-papers-can-new-toolskeep-them-afloat. Accessed 9 August 2020.

Brookfield, S. (2016). The future of social justice in adult education. Dialogues in Social Justice, 1(1), 27-30 https://journals.uncc.edu/dsj/article/view/505. Accessed 9 August 2020.

Burawoy, M. (2005). For public sociology. American Sociological Review, 70(1), 4-28. https://oi. org/10.1177/000312240507000102.

Carr, P. R. (2020a). Shooting yourself first in the foot, then in the head: Normative democracy is suffocating, and then the coronavirus came to light. Postdigital Science and Education. https://doi.org/10.1007 /s42438-020-00142-3. 
Carr, P. R. (2020b). If everything has changed, why such a focus on bailing out capitalism? The somber reality underpinning Covid-19. Postdigital Science and Education. https://doi.org/10.1007/s42438-020-00115-6.

Chang, B. (2020). From 'Illmatic' to 'Kung Flu': Black and Asian solidarity, activism, and pedagogies in the Covid-19 era. Postdigital Science and Education. https://doi.org/10.1007/s42438-020-00183-8.

Coeckelbergh, M. (2020). The postdigital in pandemic times: A comment on the Covid-19 crisis and its political epistemologies. Postdigital Science and Education. https://doi.org/10.1007 /s42438-020-00119-2.

Dick, W. (2018). What is behind the right-wing 'Reichsbürger' movement? Deutsche Welle, 24 July. https://www.dw.com/en/what-is-behind-the-right-wing-reichsb\%C3\%BCrger-movement/a-36094740. Accessed 31 August 2020.

FAO and WFP (2020). FAO-WFP early warning analysis of acute food insecurity hotspots. https://doi. org/10.4060/cb0258en. Accessed 12 August 2020.

Flaherty, C. (2020). Something's got to give. InsideHigherEd, 20 August. https://www.insidehighered. com/news/2020/08/20/womens-journal-submission-rates-continue-fall. Accessed 21 August 2020.

Freire, P. (2018). Pedagogy of the Oppressed (50th Anniversary ed.). New York: Bloomsbury.

Freud, S. (1961). Civilization and its discontents. New York: W.W. Norton and Company.

Giannini, S. (2020). Covid-19 school closures around the world will hit girls hardest.. https:/en.unesco. org/news/covid-19-school-closures-around-world-will-hit-girls-hardest. Accessed 21 August 2020.

Giroux, H. (2005). Schooling and the struggle for public life. Democracy's promise and education's challenge. Boulder \& London: Paradigm Publishers.

Green, J. K., Burrow, M. S., \& Carvalho, L. (2020). Designing for transition: supporting teachers and students cope with emergency remote education. Postdigital Science and Education. https://doi.org/10.1007 /s42438-020-00185-6.

Grossman, V. (2020). Some Come, Others Go. Berlin Bulletin No. 179, 6 August, 2020. https://www. theleftberlin.com/post/some-come-others-go. Accessed 12 September 2020.

Hale, C. (2001). What is activist research? Brooklyn: Social Science Research Council. https://items.ssrc. org/from-our-archives/what-is-activist-research/. Accessed 21 August 2020.

Hardt, M., \& Negri, A. (2012). Declaration. New York: Argo Navis. https://antonionegriinenglish.wordpress. com/2012/05/16/declaration-by-hardt-and-negri/. Accessed 7 August 2020.

Henig, R. (2020). Experts warned of a pandemic decades ago. Why weren't we ready? National Geographic. https:/www.nationalgeographic.com/science/2020/04/experts-warned-pandemic-decades-ago-whynotready-for-coronavirus/. Accessed 8 August 2020.

Horton, M., \& Freire, P. (1990). We make the road by walking: Conversations on education and social change. Philadelphia: Temple University Press.

Hurley, Z. (2020). Postdigital feminism and cultural visual regimes: Covid-19 at Women's Only University in the gulf. Postdigital Science and Education. https://doi.org/10.1007/s42438-020-00134-3.

Jandrić, P. (2020). Postdigital research in the time of Covid-19. Postdigital Science and Education, 2(2), 233238. https://doi.org/10.1007/s42438-020-00113-8.

Jandrić, P., \& Hayes, S. (2020). Writing the history of the present. Postdigital Science and Education. https://doi.org/10.1007/s42438-020-00168-7.

Jandrić, P., Knox, J., Besley, T., Ryberg, T., Suoranta, J., \& Hayes, S. (2018). Postdigital science and education. Educational Philosophy and Theory, 50(10), 893-899. https://doi.org/10.1080 /00131857.2018.1454000.

Jandrić, P., Hayes, D., Truelove, I., Levinson, P., Mayo, P., Ryberg, T., Monzó, L. D., Allen, Q., Stewart, P. A., Carr, P. R., Jackson, L., Bridges, S., Escaño, C., Grauslund, D., Mañero, J., Lukoko, H. O., Bryant, P., Fuentes Martinez, A., Gibbons, A., Sturm, S., Rose, J., Chuma, M. M., Biličić, E., Pfohl, S., Gustafsson, U., Arantes, J. A., Ford, D. R., Kihwele, J. E., Mozelius, P., Suoranta, J., Jurjević, L., Jurčević, M., Steketee, A., Irwin, J., White, E. J., Davidsen, J., Jaldemark, J., Abegglen, S., Burns, T., Sinfield, S., Kirylo, J. D., Batarelo Kokić, I., Stewart, G. T., Rikowski, G., Lisberg Christensen, L., Arndt, S., Pyyhtinen, O., Reitz, C., Lodahl, M., Humble, N., Buchanan, R., Forster, D. J., Kishore, P., Ozolinšs, J., Sharma, N., Urvashi, S., Nejad, H. G., Hood, N., Tesar, M., Wang, Y., Wright, J., Brown, J. B., Prinsloo, P., Kaur, K., Mukherjee, M., Novak, R., Shukla, R., Hollings, S., Konnerup, U., Mallya, M., Olorundare, A., Achieng-Evensen, C., Philip, A. P., Hazzan, M. K., Stockbridge, K., Komolafe, B. F., Bolanle, O. F., Hogan, M., Redder, B., Sattarzadeh, S. D., Jopling, M., SooHoo, S., Devine, N., \& Hayes, S. (2020). Teaching in the age of Covid-19. Postdigital Science and Education. https://doi.org/10.1007 /s42438-020-00169-6.

Khan, A. R., Ratele, K., \& Arendse, N. (2020). Men, suicide, and Covid-19: Critical masculinity analyses and interventions. Postdigital Science and Education. https://doi.org/10.1007/s42438-020-00152-1. 
Lewis, T. E. (2020). Cities gone wild. Postdigital Science and Education. https://doi.org/10.1007 /s42438-020-00120-9.

Lotman, Y. (2005). On the semiosphere. Sign Systems Studies, 33(1), 205-229.

Lovink, G., \& Rossiter, N. (2018). Organization after social media. New York: Minor Compositions.

MacKenzie, A., \& Bhatt, I. (2020). Lies, bullshit, and fake news: Some epistemological concerns. Postdigital Science and Education, 2(1), 9-13. https://doi.org/10.1007/s42438-018-0025-4.

McLaren, P. (2020). Religious nationalism and the coronavirus pandemic: Soul-sucking evangelicals and branch covidians make America sick again. Postdigital Science and Education. https://doi.org/10.1007 /s42438-020-00122-7.

Mills, C. W. (2000). The power elite. Oxford: Oxford University Press.

Mills, C. W. (2002). White collar. Oxford: Oxford University Press.

Morse, R. (Ed.). (1993). Emerging Viruses. New York: Oxford University Press.

O'Sullivan, V. (2020). Non-human animal trauma during the pandemic. Postdigital Science and Education. https://doi.org/10.1007/s42438-020-00143-2.

Odar, B. O. (2017-2020). Dark [TV Series]. Los Gatos: Netflix.

Peters, M. A. (2020). Philosophy and pandemic in the postdigital Era: Foucault, Agamben, Žižek. Postdigital Science and Education. https://doi.org/10.1007/s42438-020-00117-4.

Peters, M. A., Jandrić, P., \& McLaren, P. (2020). Viral modernity? Epidemics, infodemics, and the 'bioinformational' paradigm. Educational Philosophy and Theory, 1-23. https://doi.org/10.1080 /00131857.2020.1744226.

Peters, M. A., McLaren, P., \& Jandrić, P. (2020). A viral theory of post-truth. Educational Philosophy and Theory, 1-9. https://doi.org/10.1080/00131857.2020.1750090.

Rapanta, C., Botturi, L., Goodyear, P., Guàrdia, L., \& Koole, M. (2020). Online university teaching during and after the Covid-19 crisis: Refocusing teacher presence and learning activity. Postdigital Science and Education. https://doi.org/10.1007/s42438-020-00155-y.

Sebeok, T. (1986). I think I am a verb. New York: Springer.

Selwyn, N., \& Jandrić, P. (2020). Postdigital living in the age of Covid-19: Unsettling what we see as possible. Postdigital Science and Education. https://doi.org/10.1007/s42438-020-00166-9.

Shurchkov, O. (2020). Is COVID-19 turning back the clock on gender equality in academia? https://medium. com/@olga.shurchkov/is-covid-19-turning-back-the-clock-on-gender-equality-in-academia-70c00d6b8 ba1. Accessed 21 August 2020.

Simmel, G. (1950). The sociology of Georg Simmel. Glencoe: The Free Press.

Suoranta, J. (2020). Critical pedagogy and Wikilearning. In S. Steinberg \& B. Down (Eds.), The SAGE handbook of critical pedagogies (pp. 1126-1138). Thousand Oaks: Sage.

Teräs, M., Suoranta, J., Teräs, H., \& Curcher, M. (2020). Post-Covid-19 education and education technology 'solutionism': A seller's market. Postdigital Science and Education. https://doi.org/10.1007 /s42438-020-00164-x.

Vincent-Lamarre, P., Sugimoto, C., \& Larivière, V. (2020). Monitoring women's scholarly production during the COVID-19 pandemic. http://shiny.initiativesnumeriques.org/monitoring-scholarly-covid/. Accessed 21 August 2020.

Wagener, A. (2020). Crushed by the wheels of industry: War, heroes, and domestic recolonization in the time of Covid-19. Postdigital Science and Education. https://doi.org/10.1007/s42438-020-00140-5.

Yan, F. (2020). Managing 'digital China' during the Covid-19 pandemic: Nationalist stimulation and its backlash. Postdigital Science and Education. https://doi.org/10.1007/s42438-020-00181-w.

Zhu, X., \& Liu, J. (2020). Education in and after Covid-19: Immediate responses and long-term visions. Postdigital Science and Education. https://doi.org/10.1007/s42438-020-00126-3. 